\title{
RE-ORIENTING THE 'WEST'? \\ The Transnational Debate on the Status \\ of the 'West' in the Debates among Islamist \\ Intellectuals and Students from the 1970s to the Present
}

\section{Farish A. Noor}

Senior fellow, S. Rajaratnam School of International Studies (RSIS), Cluster

Group 'Transnational Religion in Southeast Asia' Nanyang Technological

University (NTU) Singapore

\section{Abstract}

This paper will look at the process of transnational transfer of ideas, beliefs and value-systems, with a special emphasis on the transfer of Islamist ideas and ideals through the vector of student movements and organisations that were set up in Western Europe and North America as well as the rise of a new generation of Islamist intellectuals in Malaysia in the late 1960s for whom the idea of the 'West' was turned on its head and re-cast in negative terms.

It begins by looking at how the 'West' was initially cast in positive terms as the ideal developmental model by the first generation of post-colonial elites in Malaysia, and how - as a result of the crisis of governance and the gradual decline in popularity of the ruling political coalition - the 'West' was subsequently re-cast in negative terms by the Islamists of the 1960s and 1970s who sought instead to turn Malaysia into an Islamic society from below.

As a consequence of this dialectical confrontation between the ruling statist elite and the nascent Islamist opposition in Malaysia, the idea of the 'West' has remained as the central constitutive Other to Islam and Muslim identity, and this would suggest that the Islamist project of the 
1970s to the present remains locked in a mode of oppositional dialectics that nonetheless requires the presence of the 'West' as its constitutive Other, be it in positive or negative terms.

Keywords: Malaysian intellectuals, politics, Islamic activism, western status

\section{A. Introduction: Faith, Reason and Education - How 'Western' Education led to the re-birth of Islamic activism in Malaysia in the 1970 s}

'Modern social science... asserted that religion would fade, then disappear, with the triumph of science and rationalism. But religion has expanded explosively, stimulated as much by secular global processes- migration, multinational capital, the

media revolution- as by proselytising activity. Contrary to expectations, its expansion has been an answer to and driven by modernity. In response to the deracination and threats of cultural extinction associated with modernising processes, religious experience seeks to restore meaning to life'.

Sussane Hoeber Rudolph, Religion, States and Transnational Civil Society. ${ }^{1}$

This paper will look at how the experience of Malaysian-Muslim university and college students in Europe from the late 1960s to the early 1990s helped to form their own understanding of Islam and consciousness as Muslim subjects. ${ }^{2}$ The paper begins by arguing that

1 Susanne Hoeber Rudoplh, "Religion, States and Transnational Civil Society", in Susanne Hoeber Rudolph and James Piscatori (eds.), Transnational Religion and Nation States, (Boulder, Colorado: Westview Press, 1997), p. 1.

${ }^{2}$ I will not be discussing the process of Islamisation in Malaysia and the rest of the Malay world as there already exists a vast body of scholarly material that has looked into the subject. For further elucidation and analysis on the topic, one could turn to the following sources: on Islam's early arrival in the Malay world, see: S. Q. Fatimi, Islam Comes to Malaysia, (Singapore: Malaysian Sociological Research Institute (MSRI), 1963); S. Hussein Alatas, "On the Need for a Historical Study of Malaysian Islamisation', Journal of Southeast Asian Studies, Vol. 4 No. 3, Singapore, March 1963; S. Naguib AlAttas, Preliminary Statement on a General Theory of the Islamization of the Malay-Indonesian Archipelago, (Kuala Lumpur: Dewan Bahasa dan Pustaka, 1963) and Russell Jones, 
the experience of the Malay-Muslim diaspora in Europe at this time was neither new nor unique: after all, Malay-Muslims have been part of a heterodox and internally differentiated global Muslim community for centuries, and it could never be said that travel to Europe was a radically different experience compared to their travels elsewhere. Neither Islam nor the wheel were re-invented through this sudden increase in the level of contact and migration between these two social spheres and there has been no radical paradigm shift in terms of the actual power differentials between North and South, East and West.

However, I am not claiming that the contact with the West and Europe in particular has been inconsequential or that it has left no traces either. But what needs to be qualified and examined further are the specific socio-political and historical circumstances of their travels and experiences in the West at that particular juncture of Malay-Muslim history. The focus will be primarily on the experiences of Malaysian Muslim students who were travelling to Europe during that period. While other similar studies have been conducted before ${ }^{3}$ on groups of

\footnotetext{
"Ten Conversion Myths from Indonesia", in Nehemia Levtzion (ed.), Conversion to Islam, (London: Holmes and Meier, 1979). On the topic of contemporary developments in the Malay-Muslim world, see: Chandra Muzaffar, Islamic Resurgence in Malaysia, (Petaling Jaya: Fajar Bakti Press, 1987); Sharon Siddique, "Conceptualising Contemporary Islam: Religion of Ideology?", in Ahmad Ibrahim, Yasmin Hussain and Sharon Siddique (eds.), Readings on Islam and Society in Southeast Asia, (Singapore: Institute for Southeast Asian Studies (ISEAS), 1985); Judith Nagata, The Reflowering of Malaysian Islam, (Vancouver: University of British Columbia Press, 1984). For a comparative approach which situates Islamic resurgence in Malaysia within a global context, see: Chandra Muzaffar, "Islamic Resurgence: A Global View", in Taufik Abdullah and Sharon Siddique (eds.), Islam and Society in Southeast Asia, (Singapore: Institute for Southeast Asian Studies (ISEAS), 1986). For an insight into the ideas and philosophy of one of the foremost Islamists and defenders of Islamisation in Malaysia, see: Syed Naquib alAttas, Islam and Secularism, (Kuala Lumpur: Angkatan Belia Islam Malaysia, 1978).

${ }^{3}$ Richard T. Antoun, "Sojourners Abroad: Migration for Higher Education in a Post Peasant Muslim Society", in Akbar S. Ahmed and Hastings Donnan (eds), Islam, Globalisation and Postmodernity, (London: Routledge Press, 1994). Antoun's study on the patterns of student migration from Jordan to Europe, though interesting and highly informative, fails to explain the discursive dynamics at work in the process of intercultural contact. His interviews with Jordanian students studying in Europe and North America reveal their own ambivalent attitude towards the West as well as their own contested understandings of their self identity.
} 
students from other countries, my own concern is to examine how and why the image of Europe began to change in the minds of this specific constituency. The paper goes on to argue that the European experience presented the Malay-Muslim students with a host of hitherto unforeseen and unexpected challenges, which were met (both individually and collectively) via the formation of stronger communal bonds and networks among the Muslim students who were living and studying there at the time.

It was in Europe that the Malay-Muslim students of the 60s-80s came to understand and appreciate their own sense of identity and difference vis-à-vis the host community (which was not always hospitable), that in turn generated new awareness and expectations of themselves as Muslims living in a world where Islam was not only not the universal standard by which all norms were set but also no longer a potent and dominant cultural, political and economic force. Europe, in this sense, provided the Malay-Muslim students with a new sociopolitical setting and discursive arena which forced them to reconfigure new understandings in order to help them explain the condition of the Muslim community at large. These new understandings and expectations were then brought home by the Malaysian students themselves, and paved the way for the further development of MalayMuslim politics in Malaysia to come. The paper will therefore end with some tentative conclusions about the state of Muslim affairs in Malaysia and Europe at the present and what might come in the near future.

\section{B. This Thing called 'The West': Shock of the New or just Continuity?}

'It was in the West that I learned what it means to be a true Muslim. Never have I felt as free to be a real Muslim as I did when I was living in Europe. My experience of studying in

England helped me to become a better Muslim when I returned home.'

Comments such as these were typical among the Malay-Muslim students who returned to Malaysia in the 1970s and 1980s after their 
sojourn in Europe and the United States. They have been recorded and documented at length by a number of Malaysian scholars who have studied the complex process of Islamic resurgence in Malaysia which began in the $1970 \mathrm{~s}^{4}$, and such statements remain commonplace among new returnees to Malaysia up till today.

While a number of scholars have cited such statements as proof of the 'new' Islamic consciousness among Malay-Muslims in Malaysia, it might be useful to point out that the same was said by that other globe-trotting Islamist intellectual and activist, Jamaluddin al-Afghani, more than a century before. Since the mid- $19^{\text {th }}$ century the West, and Europe in particular, has been the test-bed for successive generations of Muslim students, thinkers and activists for whom the experience of cultural contact with the Other has led to a radical questioning of the Self and the redefinition (and in many cases strengthening) of the boundaries between the two.

The claim that contact with the West and the experience of living in the Western world have opened up new vistas and expanded the horizons of the Muslim world must therefore be taken with a liberal dose of salt. There have been those who have argued that a 'redefinition' and 'reintellectualisation' of Islam, Islamic discourse and Islamic identity has been brought about thanks to advances in communications and transport technology which have allowed Muslims to jump onto the first jet plane they see and fly to the cultural and political centres of Europe. The internet, which has brought the Muslim world and Europe closer together, is also said to have played a part in this grand reconceptualisation of Islamic culture and civilisation. Yet all this talk of free-flow of bodies and ideas has invariably been accompanied by claims that the Muslim world has or is about to experience the creation of 'new religious and civic spheres', characterised by 'new thinking' done by 'new people' who are part of the 'new public' and who utilise the 'new media'. Eickelman and Anderson, for instance, have argued that 'a new sense of public is emerging throughout Muslim-majority

${ }^{4}$ See for instance Chandra Muzaffar, Islamic Resurgence in Malaysia; Sharon Siddique, "Conceptualising Contemporary Islam"; Judith Nagata, The Reflowering of Malaysian Islam. 
states and Muslim communities' thanks to 'new and increasingly accessible modes of communication'. ${ }^{5}$ The end result of this overabundant newness is, we are told, that 'boundaries are no longer primarily territorial. ${ }^{6}$

But just how much of this is really new, and how do we define newness in such cases? To claim that hybridity signifies the moment of the post-modern in the Muslim world is somewhat passé, considering the fact that the experience of Islam for an overwhelming majority of Muslims for the past one and a half millennia has been marked by imaginative re-invention and accommodation through the exercise of creative agency and local genius anyway. If contact with and travel to the West is meant to represent a radical break from traditionally held notions of geography and space in the so-called 'Muslim consciousness' (as if such a general essentialist category even existed), then we need to ask ourselves if the migration of Muslims to Europe during the mid- $20^{\text {th }}$ century was really a novel experience for them.

Though it could never be said that all Muslims were and are nomadic itinerant travellers, it is safe to say that they have never been a geographically fixed community either. Akbar Ahmed (1994) has noted that 'Islam explicitly encourages and even enjoins certain forms of travel, and the movement of Muslims from one part of the world to another, whatever the purpose, resonates with the historical foundations of their religion. ${ }^{7}$ The first great movement being the Prophets bijrah or migration from Mecca to Yathrib (Medina). Muslim history is full of the stories of Muslim travellers like Ibn Battuta, Ibn Khaldun, al Biruni and Cheng Ho who travelled across the globe.

These new transport and communications technologies have merely accelerated the processes and practices that have been there all along. Jet planes may be faster than steamships, email faster than faxes which were faster than the regular post, but the messages they carry today are probably not all that radically different from what was carried

5 Dale F. Eickelman and Jon W. Anderson, "Redefining Muslim Publics", in Dale F. Eickelman and Jon W. Anderson (eds.), New Media in the Muslim World: The Emerging Public Sphere, (Bloomington and Indianapolis: Indiana University Press, 1999), p. 1. 
in the past. As Appadurai has pointed out, the present forms of globalisation seem not that much different from the earlier ones. ${ }^{8}$

\section{The Coordinates of Global Islam}

With the arrival of Islam to the Malay world, the Malay-Muslims were integrated into a global network of Muslim political and economic centres and institutions of Islamic art and learning. Conversion to Islam did not mean that the Malays were relegated to the backyard of the Muslim world either: It brought about considerable strategic gains and advantages thanks to new-found access to Muslim-dominated trading routes and transport networks. The $14^{\text {th }}-15^{\text {th }}$ century Malay-Muslim coastal kingdom of Melacca (Melaka) became one of the most important commercial centres in the Muslim world and as a result the Malays felt themselves part of a global Muslim community which was then at the height of its powers and influence. Malay rulers like the Sultans of Aceh, Melaka and Johor-Riau were corresponding with European rulers and referring to the latter as their 'brother Kings' in their letters.

Up the late- $18^{\text {th }}$ to mid- $19^{\text {th }}$ centuries, the traffic between the Malay Archipelago and the rest of the Muslim world was intense. Despite the attempts by the Western colonial powers (Britain in Malaya, Holland in the Dutch East Indies and Spain in the Philippines) to control the volume of trade and human traffic within and without the Malay archipelago, it was clear that the Straits of Melacca and the South China Sea was still the 'corridors' that kept the 'rooms' of the Malay homeland together. Indonesian-Malays moved and migrated with ease throughout the archipelago and their level of contact and exposure

\footnotetext{
Ibid., p. 6.

Akbar S. Ahmed, "Islam in the Age of Postmodernity", in Akbar S. Ahmed and Hastings Donnan (eds), Islam, Globalisation and Postmodernity, (London: Routledge Press, 1994), p. 4.

${ }^{8}$ See. A. Appadurai, "Disjuncture and Difference in the Global Cultural Economy", in Public Culture 2 (2), 1990, p. 5.
} 
to the rest of the Muslim world was also considerably high, despite the hurdles placed before them. ${ }^{9}$

The arrival of the Western colonial powers and the consolidation of Western colonial rule in the Malay Archipelago did not dampen the spirits of the Indonesian-Malays, but further increased their determination to push the limits of the coloniser's new political geography. It was during the $19^{\text {th }}$ and early $20^{\text {th }}$ centuries that we see a growing number of Indonesian-Malays travelling abroad to visit the holy lands of Islam and to establish contact with (then) independent Muslim political, economic and educational centres. Malay-Muslim traders continued to travel to East Africa, the Arabian Peninsula, Hadramaut and the ports of India to trade as they did centuries before. The rise of the first generation of Malay-Muslim reformist thinkers took place at this precise juncture in the history of Malayan-Western relations, and it is hardly a coincidence if all of those Malay-Muslim reformists who were travelling abroad at that time were increasingly concerned about the lot of the Muslim community world-wide in the face of growing Western militarism and expansionism.

Up to that point, the main destinations of the Indonesian-Malays who were travelling abroad were Mecca, Cairo, Istanbul, Delhi, Deoband and Bengal. By then there were already a number of Indonesian-Malay ulama and resident scholars teaching at the educational institutions in Mecca like Sheikh Umar al-Sumbawi, Sheikh Uthman al-Sarawaki and Sheikh Ahmad Khatib of Minangkabau. Apart from Mecca, Cairo in particular was a magnet that attracted successive generations of MalayMuslim ulama, intellectuals and scholars, being as it was at that time the centre for radical Islamist reformist-modernist thinking and the

9 Both the British and Dutch colonial authorities attempted to divide the Malay archipelago between themselves and to police the territories that had come under their influence. The Anglo-Dutch Treaty of 1824 effectively drew a boundary between Peninsula Malaya and Sumatra (which today remains as part of Indonesia). But despite these measures, the volume of human traffic between Peninsula Malaya (under British control) and the Dutch East Indies never diminished. There was simply no way for either colonial power to control and police the porous boundaries between their coloniesnot least for the simple reason that these boundaries were not recognised by anyone but the colonial authorities themselves. 
home of the famous al-Azhar university, made famous by the prominent Egyptian Islamist scholar Muhammad Abduh. Among the more prominent Malay-Muslim activists and scholars who travelled to Cairo and Mecca at that time were Syed Sheikh Ahmad al-Hadi, Sheikh Mohamad Tahir Jalaludin al-Azhari and Sheikh Muhammad Basyuni Imran.

To sum up, it could be said that right up to the earlier half of the $20^{\text {th }}$ century the Malay-Muslims of the archipelago were well and truly 'wired' to a global Muslim community that was held together by a complex array of media, communications and transportation networks. Malays in the archipelago were not only travelling abroad for education and work, they were also receiving information and news from other parts of the Islamic world via this highly efficient system of communication. Thus the Malays were kept abreast of developments in other parts of the Muslim world all the time and the Malay-Muslim intelligentsia in particular were attentive to the latest currents of ideas, debates and upheavals that were taking place elsewhere in the Muslim world- such as the Balkans crisis, the Caliphate controversy, the Khilafat movement and the question of whether Muslims should support the axis powers or the western bloc during the years leading up to the Second World War. What requires further interrogation is the claim that the experience of travel to Europe in particular was different from the experience of travelling to other parts of the Muslim world. Now, that is a different story altogether:

Even in the Malay world (long thought of by Orientalist scholars as a 'periphery' domain within the Muslim world) the movement of Malay-Muslims to other parts of the globe was far from small or diminished by the advent of colonial rule. Nor did the arrival of 'new' transport and communications technology leave the Malay-Muslims dumbfounded. Contrary to the thesis put forward by the likes of Gellner, ${ }^{10}$ Muslims were more than capable of dealing with advances in technology even when they were no longer at the forefront of technological innovation. They did not stare blankly at the huge ocean liners that breathed smoke and fire, wondering what they were or how

\footnotetext{
${ }^{10}$ Ernest Gellner, Muslim Society, (Cambridge: Cambridge University Press, 1981).
} 
they worked. They simply bought their tickets and sailed off to Mecca and Cairo. But Cairo and Mecca were not the only destinations of the Malay-Muslims. What is equally important to note is that during the same period (mid-19 ${ }^{\text {th }}$ to mid-20 ${ }^{\text {th }}$ century) there was also a large number of Malays who were travelling to the West for a number of reasons.

British colonial rule brought about important structural and institutional changes to the way that the Malay lands were governed. (The same holds true for Indonesia and the Philippines which came under Dutch and Spanish rule respectively). The poly-nuclear world of the Malay Archipelago was systematically mapped out, demarcated, divided and ruled by the competing colonial powers who introduced centralised rule in one way or another. While keeping the local insurgent forces at bay, the British, Dutch, French, Spanish and American colonisers in Southeast Asia were also keen to accommodate and incorporate the native rulers and traditional elite into their respective colonial administrative frameworks. Institutions of higher learning were built, with the specific aim of imparting colonial (not to be confused with Western) education to the offspring of the local rulers and aristocrats themselves.

Apart from the Malay Sultans, there was also a growing number of Malay-Muslims travelling to Europe (and Britain in particular) for the sake of education. The political realities of the time had convinced the members of the Malay-Muslim ruling elite that the sun of the British Empire was not about to set just yet. And as long as it didn't it would be in their own interests to send their sons to that corner of the world to learn the ways and mores of their uninvited colonial masters. Thus it was that from the early to mid- $20^{\text {th }}$ century onwards we begin to see a growing number of Malays (mostly from the elite strata) travelling to Europe in order to gain entry into Western institutions of higher education. Among them were men like Tunku Abdul Rahman Putra Al-Haj (who later became the first Prime Minister of Malaysia), Tun Abdul Razak (who became the second Prime Minister), Tengku Razaleigh Hamzah and Datuk Harun Idris. It was in London that men like Tunku Abdul Rahman, Tun Razak and Tengku Razaleigh Hamzah first met and it was there that the nucleus of the conservative MalayMuslim UMNO party was formed. 
This trend remained unchallenged right up to the post-war years of the 1940s and 1950s: While the members of the Malay-Muslim elite and aristocracy travelled to the West to further their education, the scions of the Malay-Muslim lower-middle classes were still being sent to centres of learning in the Arab-Muslim world like their fathers had done. Thus while the future leaders of the conservative United Malays National Organisation ${ }^{11}$ (UMNO) party were being educated in Oxford and Cambridge, the future leaders of the Pan-Malaysian Islamic Party ${ }^{12}$ (PAS), like Dr. Burhanuddin al-Helmy, Dr. Zulkiflee

${ }^{11}$ The United Malay Nationalist Organisation (UMNO) was formed in 1946 after a Pan-Malayan Congress that brought together all the major Malay-Muslim political groupings of the country. The Congress included representatives of the conservative, leftist, nationalist and Islamist camps, but the leftists soon left the movement altogether. UMNO was formed in the same year and it remains the most dominant party in Malaysia today, with more than two and a half million members. It was formed in 1946 as a conglomeration of Malay nationalist organisations. UMNO's ideological stand remains right of centre, with strong neofeudal and conservative-traditionalist elements in the party's culture. UMNO has also been at the head of the ruling alliance which has been in power in the country since independence was granted in 1957. At first the Alliance (Perikatan) was made up of UMNO, the Malaysian Chinese Assembly (MCA) and the Malaysian Indian Congress (MIC). In 1974 the Alliance was disbanded and replaced with the National Front (Barisan Nasional) coalition that included UMNO, MCA, MIC and others parties such as Gerakan, PPP, SUPP, Berjasa, and even the Islamic party PAS (which joined the coalition between 1973 to 1978).

${ }^{12}$ The nucleus of the Pan-Malaysian Islamic Party (PAS) lay in the Bureau of Religious Affairs of the conservative-nationalist Malay party, UMNO. By the early 1950s, the Ulama and religious leaders within UMNO felt that the time had come for them to break away from the nationalist organisation and form a party of their own. This was due to the conduct and poor leadership shown by the UMNO leaders themselves like Dato' Onn Jaafar. In 1951, PAS was formed under the leadership of Haji Fuad Hassan, who was the head of the UMNO bureau of religious affairs. By 1956 the party members felt that their party needed a new leader with greater vision and political commitment. The radical nationalist and Islamist thinker Dr. Burhanuddin al-Helmy was then invited to take over as president of PAS at its fifth conference in December 1956. Between 1956 to 1969 , the combined leadership of Dr. Burhanuddin and Dr. Zulkiflee Muhammad (the party's vice-president) managed to broaden the political base of PAS and open it up to the rest of the Muslim world. Both men were veteran activists who had studied abroad. Dr. Burhanuddin had studied at Aligarh while Dr. Zulkiflee at al-Azhar. During the elections of 1959, 1964 and 1969, PAS managed to do quite well and it came to power in the state of Kelantan. In 1969 Dr. Burhanuddin passed away after being put 
Muhammad and Ustaz Yusuf Rawa, were being educated at Aligarh, Mecca and al-Azhar.

Up to the 1950s at least, it appeared as if the trend of parallel education and overseas networks would remain unchallenged. But the vicissitudes of politics and changing perceptions of the West (and East) would soon change all that for good.

\section{Shifting alliances and new co-ordinates: The political factors shaping Malaysian perceptions of Europe and the West in general from the 1960s to the 1980s.}

The twentieth century witnessed the rise and fall of a number of Asian states and kingdoms stretching from India to China. But the dominant notion that the Western nations were invulnerable was shattered at the battle of Tsushima (during the Japo-Russo war), when the Japanese imperial navy destroyed the entire Russian Pacific fleet. The effect of Japan's victory was felt throughout Asia and the Muslim world. Suddenly it appeared that the 'white races' of Europe were not invincible after all. The Muslim kingdoms and states were even more impressed: delegations were sent from Egypt, Turkey and Arabia to try and convert the Japanese to Islam, if not the Islamic cause. ${ }^{13}$

The growing scepticism about the invulnerability of Europe was further intensified with the onset of the Second World War. Japan began

under detention without trial by the Malaysian government. PAS then came under the leadership of Mohamad Asri Muda, who was a staunch defender of Malay rights and privileges. Between 1970 to 1982, Asri Muda brought PAS into the ruling Barisan Nasional coalition and out again (1973-1978). The period of Asri Muda's leadership was highly controversial one. The president himself was involved in a number of major corruption scandals and later accused of abusing his power within the party. In 1982, Asri Muda was forced to step down by a new generation of Islamist ulama who had infiltrated the party from ABIM. The 1980s and 1990s witnessed the radicalisation of PAS as its new leaders began to confront the UMNO-led coalition government and the state apparatus on the grounds that the latter were 'secular', 'unIslamic' and working in league with Western and Zionist interests. In 1990 PAS regained control of the state of Kelantan, and in 1999 it won control of Trengganu as well.

${ }^{13}$ For a fuller description of these delegations to Japan and the complex debates within the Muslim world that took place at the time after Japan's victory over Russia, see: Martin Kramer, Islam Assembled: The Advent of the Muslim Congresses, (Columbia University Press, 1986). 
its invasion of Malaya with the sinking of the British warships H.M.S Repulse and Prince of Wales, and followed up with an immediate attack on Malaya itself and the capture of Singapore. By the end of the campaign, thousands of British and Dutch soldiers had been taken prisoner and with them went the image of the European 'sahib' who could command the respect and awe of the natives. Indonesia, Burma and the Philippines declared their own independence and the European powers realised that they would never be able to maintain their colonies in Southeast Asia ever again.

Malaya (later Malaysia, from 1963) gained its independence in 1957- more than a decade after Indonesia, Burma and the Philippinesand its own history has been somewhat different ever since. While the other leaders of Southeast Asia (most notably Sukarno of Indonesia) were denouncing the West and accusing European and American powers of trying to destabilise and topple the newly-emerging forces (Nefos) of the East, the Malaysian Prime Minister Tunku Abdul Rahman was busy trying to secure Malaysia's entry into the Commonwealth and other Western-dominated military and economic alliances like SEATO (the Southeast Asian Treaty Organisation, dominated by Britain and the United States).

Because of the consensus of values and ideology that already existed between the rulers of Britain and Malaya, the transfer of power and authority from the departing colonial powers to the traditional Malay ruling elite proved to be uncomplicated. In the words of Chandra (1987): 'both feudal history and British colonialism had thus conspired to bestow the privilege of power upon this (Malay elite) group'. ${ }^{14}$ Unlike Indonesia which had nationalised all Dutch assets when it declared its independence, the conservative government of the Federation of Malaya safeguarded the economic interests and investments of the British even after they had left. ${ }^{15}$ Malaya's Prime Minister Tunku Abdul Rahman spoke of the 'special relationship' between Malaya and Britain

\footnotetext{
${ }^{14}$ Chandra Muzaffar, Islamic Resurgence in Malaysia, p. 59.

${ }^{15}$ Abdullah Ahmad notes that even after independence, 'rubber, tin, banking, insurance, shipping and the oil industry were all in British hands' (p. 8). This in turn affected Malaya's foreign policy vis-à-vis the Western powers and Britain in particular.
} 
while the image of post-war Europe, and Britain in particular, was a highly ambivalent one at this stage in Malaysia.

On the one hand, Europe's image had been severely dented thanks to the traumatic experience of the Second World War. The conflict which began in the West and soon spread to the rest of the world had convinced Asians and Muslims worldwide that the image of Western civilization was an illusory one. Europe was also home to the Western powers that were not too long ago the colonial masters of Asia and the Muslim world. It was hardly a surprise then that their excolonial subjects did not harbour particularly endearing memories of them, or any longings to have them back.

But Europe's seemingly miraculous recovery in the wake of the Second World War (financed to a considerable extent by the Marshall Plan of the United States) was also a source of inspiration for many of the leaders of Asia and the Muslim world, and Malaya was not an exception to the rule. It was at this time that the political and business elite of Malaya (like many other parts of the Muslim world) looked to the West for guidance and instruction on how to get their economies and governments in order. The relationship between Malaya and Britain (and the West in general) was therefore predicated on a chain of equivalences $^{16}$ (to borrow Ernesto Laclau's phrase) which equated Europe with everything that was good.

${ }^{16}$ The term 'chain of equivalences' is taken from the work of Ernesto Laclau and Chantal Mouffe. Laclau and Mouffe have argued that such chains of equivalences are formed when there are attempts to instrumentally link together disparate elements and ideas for specific (political) ends. Thus, the idea of the West can be linked to other unrelated concepts like 'civilisation', 'modernity' and 'progress' via the adept and skillful manipulation of language for political purposes. This does not, however, mean that there is any natural connection between these terms and concepts, and it obviously follows that each chain of equivalences is an unnatural, non-essential construct that can only be maintained through certain hegemonic practices. Nonetheless, Laclau and Mouffe have argued that such practice is indeed commonplace in political activity in general and the struggle to define, create, break and disarticulate different chains of equivalences is part and parcel of the struggle for hegemony in political life. See: Ernesto Laclau and Chantal Mouffe, Hegemony and Socialist Strategy: Towards a Radical Democratic Politics, (London: Verso Press, 1985). 


\section{First Chain of Equivalence: 'West Good, East Bad'}

'The vanquished always want to imitate the victor in his distinctive characteristics, his dress, his occupation, and in all his other conditions and customs. (They) consider the victor perfect, either because they are impressed by the respect they have for him, or because they erroneously assume that their own subservience is not due to the nature of their defeat but to the victor's perfection. If that erroneously assumption fixes itself, it becomes a firm belief. The vanquished then adopts all the manners of the victor and assimilate themselves to him.

...This, then, is imitation'. Ibn Khaldun, The Muqadimmah ${ }^{17}$

Ibn Khaldun's perceptive observation (quoted above) sums up the predicament of what Franz Fanon called 'the mentality of the colonised', and such prejudice was certainly not in short supply among the first generation of Malaya's political and economic elite.

From the mid-1940s to the early 1950s, Malaya's political elite saw Europe and America as the shining beacons of instrumentalist rationality, material development, economic progress, universalism, cosmopolitanism and human rights (the very subjects of this conference). Europe was, for the leaders of the newly-independent countries in Asia and the Muslim world, the birthplace of the renaissance and the Enlightenment. It was home to Adam Smith, Newton, Rousseau, Voltaire, Kant and Einstein as well as being a cornucopia that was brimming with new-found inventions.

It was clear that at that stage of Malayan-European relations, the Western world was still able to mesmerise the political elite of the newly-independent country. The very idea of Europe, apparently rocksolid as it stood on its universal foundations, still possessed considerable hegemonic power over the rest of the world. And it was precisely this hegemonic dominance that allowed the West to relegate Asia and the

\footnotetext{
${ }^{17}$ Ibn Khaldun, The Muqadimmah, trans. R. Rosenthal, p. 116.
} 
Muslim world to the periphery, as Hall and Gieben have argued. ${ }^{18}$ The mapping of the world according to the Eurocentric imaginary effectively created neatly compartmentalised distinctions between the developed and under-developed, civilised and un-civilised, rational and irrational, enlightened and obscurantist, progressive and backward. Needless to say, 'Europe' was linked to the first range of categories while the rest were lumped with the other. This chain of equivalences was obviously an instrumental fiction that had no fundamental grounding in any 'European essence' or primordial genius that was unique and exclusive to Europeans alone, but it was underpinned by very real structures and institutions of power, control and dominance which ensured that the positive categorisation of Europe would remain uncontested.

Cognisant of the new political realities that stood before the newly independent state, Malaya's leaders began to formulate their foreign, domestic and education policies accordingly. Under the leadership of Tunku Abdul Rahman Malaya spent more on education that any other country in Southeast Asia (a trend that persists till today) and the government was keen to send the best and brightest among the youth to the West to study. Malaya began sending thousands of young Malay-Muslim students to study abroad in Britain and the United States- both of which were anglophone countries while the former was particularly favoured for its academic system which was compatible

\footnotetext{
${ }^{18}$ See: Stuart Hall and Bram Gieben, "The West and the Rest: Discourse and Power", in Stuart Hall and Bram Gieben (eds.), The Formation of Modernity, (Cambridge: Polity Press, 1992). Hall and Gieben have argued that the concept of the 'West' (here meant to be understood as encompassing Western Europe and North America) was never a concrete bloc or unified entity, but rather a discursive construct that operated on a number of different discursive registers. The notion of a unified West was invariably projected in much of Western political, academic and economic discourse. In most cases, the deployment of the concept was intended to help create a boundary effect between the West and the rest, mapped out according to a eurocentric geography which placed Europe (and later America as well) at the centre of the world. This eurocentric view of the world helped to consolidate Europe's own hegemonic grasp on other cultures and societies. It allowed for, and justified, policies and measures that invariably placed the West on unequal terms with the rest and projected the Western model as the norm to be emulated on a global (thus universal) level.
} 
to that of Malaya's. Malayan students were sent to study in both arts and sciences, and Britain was the favourite destination for those who wanted to enter the Malayan civil service.

Britain under the leadership of Harold MacMillan had managed to re-start its economy and was beginning to introduce the first constitutional and institutional reforms that would pave the way for a welfare state. For ordinary Malayans, the colonial metropole seemed to embody all that was worthy of emulation. They spoke of the free health and education services in glowing terms, painting an image of Britain as the land of milk, honey, subsidised housing, central heating and free dental check-ups. Malayans were also impressed by Britain's election process (the first elections in Malaya were only held in 1955) and the freedom of expression enjoyed by the vocal press in the country.

Britain's liberal-capitalist system also seemed to promise Malayans the goods and services they had been dreaming of for decades. Malayan students and elites alike travelled to London (and the other capitals of Europe and America) to stock up on goods that could not be found back home in Malaya. The elite were keen to emulate the glamorous life-style of Europe's rich and famous, with whom some of them got along famously. (Tunku Abdul Rahman was well known in European diplomatic and governmental circles. His anglophile inclinations endeared him to many European politicians who regarded him as someone they 'could do business with' and his own feudal background made him feel all the more comfortable in London's gentlemen's clubs.)

But while Malaya's elite were busy playing court with the political and business elite in Europe, other shifts and changes were taking place on the international scene that would later alter the popular perception of the West in the eyes of the Malayans back home.

\section{Second chain of equivalence: 'East Good, West Bad'}

They (Westernised Muslims) have all become conscious or unconscious agents of Western culture and civilisation, and in this capacity they represent what we have identified as the external sources of our Muslim dilemma... In their present condition they pose as the 
external menace which has become a grave internal problem, for intellectually, dar al-harb has advanced within dar-al-Islam; they have become the enemy within'. Syed Muhammad Naquib al-Attas, Islam and Secularism ${ }^{19}$

Popular though they were, the Tunku's parties could not go on forever. By the late 1950s and early 1960s, newly-independent Malaya found itself being rapidly out-manoeuvred on the international level by other more aggressively anti-Western countries and leaders like Indonesia's Sukarno and India's Nehru. Malaya's close relationship with Britain (which was underpinned by its dependency on the West for capital investment as well as military assistance) made it appear as the dark horse in the stable of the newly-independent countries that were in the non-aligned movement. The anglophile and eurocentric proclivities of Malaya's leaders and ruling elite also singled them out at the numerous South-South conferences where every Third World leader was expected to pepper his speeches with barbed invectives directed towards the evil forces of neo-colonialism and neo-imperialism that were hovering above the Southern nations like predatory vultures.

When Tunku Abdul Rahman announced the plan to expand the Federation of Malaya by including Singapore, Sarawak and Sabah (the latter two from North Borneo) in 1963, ${ }^{20}$ Malaya's neighbours were incensed. The leaders of Indonesia and the Philippines denounced the move as a betrayal on the part of Malaya- which they accused of acting as the Trojan horse for British and American neo-colonial interests. Goaded by the Indonesian Communist leader Dwipa Nusantara Aidit and under pressure from the Indonesian Communist Party (PKI) with

${ }^{19}$ Syed Muhammad Naquib al-Attas, Islam and Secularism, (Kuala Lumpur: ABIM (Angkatan Belia Islam Malaysia) Press, 1978), p. 128. For a critique of the works and ideas of al-Attas, see: Mona Abaza, Rethinking the Social Knowledge of Islam: Critical Explorations in the Islamisation of Knowledge Debate between Malaysia and Egypt', unpublished Doctoral thesis for the Wissenschaftskolleg zu Berlin, Berlin, 1998, esp. Chapter 6, pp. 85-107.

${ }^{20}$ The Federation would henceforth be renamed the Federation of Malaysia. In 1965 Singapore broke away from the federation due to increasing inter-ethnic tension between the Malays and the Chinese (who were a majority in Singapore). The two states of East Malaysia have remained in the country. 
whom he was allied, Sukarno unilaterally declared a military campaign to 'crush Malaya' ('ganyang Malaya') which became known as the Konfrontasi of 1963-1965.

Sukarno's decision to declare Konfrontasi against Malaya came as the biggest blow to the links between the Malayan and Indonesian Malay-Muslim movements. For up to the mid- $20^{\text {th }}$ century the level of contact and movement between the peoples of the Malay archipelago was exceedingly high. Even during the height of colonial power and influence in the region, the movement of people, goods and ideas within the archipelago was never arrested or fully controlled. However, as soon as hostilities between Malaysia and Indonesia were declared, it became practically impossible for the Malay-Muslims of Malaysia to maintain contact with their Indonesian counterparts. Malaysian students who were studying in the madrasabs and pesantrens of Indonesia were immediately ordered to return home and then re-directed to Europe or the Middle-East instead. After centuries of transnational contact, the Malay-Muslim world was split apart once more thanks to Sukarno's decision to bend to the will of the Communists.

The Konfrontasi with Indonesia had also taught the Malaysians a few other lessons. By 1963-65, Malaysians had begun to realise that their own role in the region and their close relationship with the West and Britain in particular was seen as problematic by the other neighbouring states of Southeast Asia.

The 1960s witnessed the emergence of popular anti-colonial and anti-Western movements the world over, and the influence of their movements, their ideas and their leaders could be felt everywhere in Malaysia. It was during this time that the leadership of the PanMalaysian Islamic party (PAS), then under the capable guidance of its most sophisticated and vocal president Dr. Burhanuddin al-Helmy, began to attack the Malaysian government for its dependency on European and American powers. In his speeches, Dr. Burhanuddin (who was a fervent admirer and follower of Sukarno in his youth) condemned the leadership of Tunku Abdul Rahman and the UMNOled government for their betrayal of Malay-Muslim interests and for their willingness to bend over backwards to meet the demands and conditions imposed by the West. The more articulate among the PAS 
leaders attacked the Malaysian government for not doing enough to nationalise the assets of the departed colonial powers and for signing numerous military pacts with Britain in particular that jeopardised Malaysia's standing as a neutral country and a member of the nonaligned movement. Dr. Burhanuddin cited the example of Muslim countries (like Egypt under Gammel Nasser and Indonesia under Sukarno) that had defied the will of the capitalists of Europe and America by nationalising the major industries of their respective countries and introducing the fundamental structures of a welfare state.

It was during this period that the political mood in the country began to take a radical turn. PAS, under Dr. Burhanuddin, had been transformed into a radical leftist-Islamist party that was vehemently opposed to all forms of neo-colonialism and neo-imperialism. The leaders of PAS injected into their followers and supporters a new level of political awareness that made them see the struggle of Asians and Muslims worldwide as their own. They condemned the conduct of European and American troops in the Korean War and the Vietnam War that came after. They also condemned the European powers for their continued interference in their ex-colonies. Britain's meddling in parts of Africa; France's part in the brutal conflict in Algeria; America's shady intrigues in Iran, Vietnam and Indonesia and Belgium's sordid role in the assassination of the Congolese nationalist leader Patrice Lumumba became the topics of the day that painted a new portrait of Europe in lurid colours.

Thanks to the combined efforts of its external and internal critics, Europe had finally been decentred and dethroned. But this decentring of the West also opened the way for the deperipheralisation of the rest of the world, as Sayyid (1997) puts it:

Decentring does not refer solely to the unity of the West, but also to the relation between the West and the rest. If the West is decentred, it must be decentred in relation to the non-West; for without a centre there can be no periphery. The decentring of the West means that the non-West can no longer be treated as the periphery. ${ }^{21}$

${ }^{21}$ Bobby Sayyid, A Fundamental Fear: Eurocentrism and the Emergence of Islamism, (London: Zed Books, 1997), p. 110. 
Thus by the 1960s, a new chain of equivalences was being created thanks to the incessant critiques against Europe and the West in general by the radical leftist and Islamist opposition leaders in Malaysia and the rest of the non-Western world. With the decentring of Europe and the Western ideal, the way was now open for a different image of Europe to be drawn by the non-Europeans themselves.

Whereas Europe in the 1950s was seen by Malaysians as a promised land of hope and renewal, the same Europe from the mid1960s onwards was seen as the source of many (if not all) of the ills of the rest of the world. The liberal-capitalist culture of Europe was no longer a source of precious and eagerly sought goods and services: Instead it became synonymous with moral decadence, corruption, abuse of power and structural inequalities that incurred their human cost on other parts of the world. The pattern of growth and social development in Europe was no longer seen as rationalistic (or if it was then it was re-cast as a form of instrumentalist rationality taken one step too far, which had brought Europeans to the brink of social collapse and environmental disaster). Worse still, Europe and European culture was seen as having a morally corrupting influence on the value and belief systems of Asians and Muslims worldwide. The outlandish and flamboyant escapades and shenanigans of Asian and Muslim leaders in Europe angered the more conservative, traditional and impoverished sections of their own communities.

In countries like Iran, Turkey, Pakistan, Egypt and Malaysia, the experiment with European-style modernisation and development undertaken by the respective regimes had encountered serious difficulties. Under the rule of the Pehlavi dynasty, Iran had managed to develop its economy, military and bureaucracy but at the expense of civil liberties and public freedom. In 1953 Iran experienced a political crisis when the popular leader Mohammad Mosaddeq and his Tudeh party came to power, ousting Muhhamad Reza Shah.

In the few countries where the Islamists had actually managed to secure some kind of foothold on the political system, they found that they achievements were reduced to naught by secular anti-Islamist leaders who were not prepared to engage with the forces of Islamic resurgence itself. When the Pan-Malaysian Islamic Party managed to 
gain control of two state governments (Kelantan and Trengganu) after the federal elections of 1959, they found themselves at the receiving end of the state's anti-Islamist polemics. PAS was denounced by the anglophile and Westernised leaders of UMNO as a party of 'extremists' and 'fanatics' who were bent on chopping off the heads and hands of criminal offenders. The leaders and members of the Islamist party were cast as backward country peasants who had no ideas about how to run a state, much less the country.

In time, the dependency of the Muslims on the West, both in terms of direct financial and military support as well as a source of political theories and developmental models, became an issue in itself. Several modern Muslim intellectuals began to condemn the influence of Western ideas and secular values in the mindset of Muslims, claiming that the corrupting influence of 'Occidentalisis' was the key factor explaining the intellectual and political frailty of the Muslim Ummah. The Iranian intellectual Jalal-e Ahmad's book Gharbzadegi (Occidentalisis) that was published in 1962 provided such a critique.

Such ideas were also gaining currency in other parts of the Muslim world, and the Malay-Muslim students who were being sent to Europe in the 1960s-1970s had their own ideas about the old world they were about to discover. What they found was a Europe wracked with problems and internal contradictions of its own that fit neatly with the image of the West that they had come to inherit from the new generation of Islamist and Leftist radicals who had taken over the opposition parties, newspapers and campuses in their own country. The stage was therefore set for a cultural marriage of inconvenience that none of the technocrats in the Ministry of Education had prepared for.

\section{Go West, Young Man: The experience of the Malay-Muslim Student Diaspora in Europe during the 1960s and 1970s}

'The rise of Islamism was only possible when the availability of Islam could be articulated into a counter-hegemonic discourse' Bobby Sayyid, A Fundamental Fear: Eurocentrism and the Emergence of Islamism ${ }^{22}$

\footnotetext{
${ }^{22}$ Ibid., p. 73.
} 
By the late 1960s and early 1970s, the discursive terrain in Malaysia (as well as many other parts of Asia and the Muslim world) had begun to shift once again. Malaysia, being both an Asian country as well as a member of the Organisation of the Islamic Conference (OIC) was caught up in both currents and its domestic political environment was altered accordingly. This in turn had serious and lasting repercussions on its relationship with Europe and the West in general.

The first moves in the new game were made by men like Sukarno, Muammar Ghadaffi and Zulfikar Ali Bhutto of Pakistan. Sukarno had tried to forge a working coalition between the Islamists, Leftists and Nationalists of Indonesia (the so-called NASAKOM alliance) and found that the best way of bringing the warring factions together was to offer them a convenient enemy: the West. But it was Muammar Ghadaffi who later got the ball rolling when he launched his hugely popular people's revolution in the wake of the coup against Sultan Idris in 1969. His attempt to promote his own school of 'Islamic-Socialism' culminated in the infamous 'Green Book' which laid out the guidelines for the complete take-over of the private sector by the ordinary Libyan masses and the setting up of a popular people's government in the country. A liberal dose of Ghadaffi's own brand of 'progressive Islam' was added to the recipe, in order to give the revolution a moral and theological basis that would resonate with the populace. ${ }^{23}$

It is important to note that in the case of Sukarno, Ghadaffi and Bhutto we encounter examples of 'reversed Orientalism' at work. Their impressive projects were fundamentally different forms of nation-

${ }^{23}$ Colonel Muammar Ghadaffi finally launched the people's revolution (jamabiriyab) in Libya in March 1977. The country's name was changed to the 'Socialist People's Libyan Arab Jamahiriyah'. Working according to the economic policy formulated in his Green Book, Ghadaffi later turned the country into a decentralised people's socialist collective where workers were encouraged to take control of factories and businesses. Private retail trade was wiped out, and citizens and workers committees took over local government. Ghadaffi also promoted his brand of 'socialist Islam' and attacked the ulama who he regarded as being backward and reactionary. The ulama in turn attacked Ghadaffi's version of socialist Islam as being bid'a (unlawful innovation) that was contrary to the teachings of Islam. Ghadaffi's response was simply to have the uncoorperative ulama thrown in jail along with the rest of the 'people's enemies' and remnants of the 'feudal era'. 
building that was a curious melange of modernist ideas and essentialist notions of what an 'authentic' and 'pure' Islam was like. All of them claimed that theirs was an attempt to 'return' Islam to its original state, to revive the internal dynamics within Islam and to liberate the collective Muslim consciousness from the chains of political, economic, military and cultural dependency on the West. Europe and America loomed large in the discourse of these leaders, and the West was invariably painted in caricatured terms that nonetheless served its purpose as the instrumental fiction that was required in order to animate the logic of their grand designs. Reactive though their projects may have seemed, there was nonetheless an element of creative agency at work which made it a radical transformative endeavour. As Nicholas Thomas puts it:

Even if (political) resistance seems to entail merely a return to former circumstances, of indigenous sovereignty and cultural autonomy, the struggle to recreate such conditions nevertheless engenders novel perceptions of identity, action and history. What appears to be simply reactive or retrogressive thus amounts to a project, to a whole transformative endeavour. ${ }^{24}$

The other important factor to note is that the image and idea of Europe was (and remains) a crucial defining element in the entire enterprise of political Islamism. The assertion of a reactive Islamic identity- in whatever essentialist terms it might be couched- requires nevertheless the presence of Europe as its constitutive Other. Europe therefore becomes the key foundational element that props up the project of Islamic revivalism in this sense. As Chandra notes:

Opposition to Western thought has continued to play a vital role in strengthening and sustaining the (Islamist) movement. It is not just rejection of secularism but also of modernism, nationalism, capitalism, socialism and indeed every other 'ism' that the West has spawned. ${ }^{25}$

In the end, saying 'no' to Europe became another way of saying 'yes' to Islam. Though the form and content of that Islam remain

${ }^{24}$ Nicholas Thomas, Colonialism's Culture: Anthropology, Travel and Government, (London: Verso Press, 1995), p. 87.

${ }^{25}$ Chandra Muzaffar, Islamic Resurgence in Malaysia, p. 21. 
undefined, what was important was the creation of the boundary-effect that drew the political and ideological horizons between Islam and the West, the Muslim world and Europe.

Malaysia was not immune to the changes that were taking place all over the Islamic world at the time. In 1972 Malaysia's second Prime Minister Tun Razak was invited to visit Lahore to attend the second Organisation of the Islamic Conference (OIC) summit hosted by Pakistan. During the visit Tun Razak had the opportunity to meet with other prominent leaders like Zulfikar Ali Bhutto, Muammar Ghadaffi and Kenneth Kaunda of Zambia. The OIC summit had a 'tremendous impact' on Tun Razak, who congratulated Bhutto for his adroit handling of the event. ${ }^{26}$ But it also convinced Tun Razak of the need for Malaysia to play a more visible and active role on the international scene and the Islamic conference in particular. Tun Razak was undoubtedly impressed by the way that Bhutto had managed to orchestrate such a high-profile event that did wonders for his own Islamist credentials. If Bhutto could open the first International Seerat Congress to commemorate the life and teachings of the Prophet Muhammad, then surely the politicians of Malaysia could surely do the same. It was at this time that the Malaysian government began lay down the foundations for what would later become its own statesponsored Islamisation programme. UMNO, under Tun Razak, was already boasting that it had managed to facilitate the conversion of 75,000 Malaysian non-Muslims to Islam thanks to its own dakwah (missionary) activities. ${ }^{27}$

\section{Homesick in London: The Dream of Islamic Revival among the Malaysian- Muslim Diaspora}

The Malaysian students who were travelling to Europe then were themselves the products of this new era. An overwhelming majority of them were from lower-middle class families, many of whom were

${ }^{26}$ Stanley Wolpert, Zufi Bhutto of Pakistan: His Life and Times, (Karachi: Oxford, 1993), p. 234.

${ }^{27}$ The highest rate of conversions to Islam then was in the East Malaysian state of Sabah, which was under the rule of its Chief Minister Datuk Mustapha Harun. 
themselves first generation migrants to the cities. They were mainly the benefactors of the pro-Malay New Economic Policy ${ }^{28}$ (put into place in 1970) and the targets of the UMNO-led government's own Islamisation programme. Chandra's (1987) general description of the average Malaysian student of the 1970s sums up the problems and internal contradictions that they brought with them to Europe:

From the 1970s onwards, a new type of Malay student began entering the institutions of higher learning in the country and abroad. Unlike the small clusters of Malays in the 1950s and early 1960s who generally came from wealthier families, students in the post-1970 period were more rural in origin. Less wealthy and more deeply attached to religious rituals and symbols, they also tended to be much more fluent in Malay rather than in English. Besides this, they also seemed to be less analytical and critical in their thinking... This background - affected their total outlook. Less confident and less secure, both emotionally and intellectually, many of these students did not want to encounter new ideas and new theories, with all the doubts and uncertainties that accompany such an adventure. They would rather stick to what was familiar; they would rather derive comfort and solace from the little knowledge they had accumulated, sanctified by religion and authority. Students in such a frame of mind were very susceptible to the sort of argument that suggests that knowledge outside of traditional Islam was nonsense, that ideas from the West were dangerous and destructive and that secularism was the greatest enemy of mankind. ${ }^{29}$

For this generation of Malay-Muslims, it was Islam that was rapidly becoming the central pillar to their own sense of identity.

${ }^{28}$ The New Economic Policy (NEP) that was launched in 1970 was meant to secure two important goals: the eradication of poverty irrespective of race and the restructuring of the Malaysian economy to the end that economic differences will no longer be identified with race. Jomo (1986) has noted that 'as it was officially elaborated, the first poverty eradication prong of the NEP was certainly not to be achieved by eliminating class exploitation. The established interests of the property owning classes were respected, at least in principle. Efforts to improve the lot of wage earners, beyond employment promotion measures, were virtually non-existent. The measures for poverty eradication that were announced did not offend existing propertied interests, and hence no land reform for example'. For a further critique of the NEP, see Jomo K. Sundaram, A Question of Class, (1986), pp. 256-260.

${ }^{29}$ Chandra Muzaffar, Islamic Resurgence in Malaysia, pp. 30-31. 
Malaysia's entry into the OIC, the country's move closer to other Muslim states and the Islamisation programme that had begun in the country (initiated by UMNO, in a bid to out-flank its opponent PAS) all contributed to the growing awareness of Islam and the sense of Muslim identity among Malay-Muslims, particularly among the younger generation of rural migrants to the cities. This was also a time when Malaysia was experiencing the first wave of 'Islamisation from below', with new non-governmental Islamist organisations like the Angkatan Belia Islam Malaysia (Malaysian Islamic Youth Movement- ABIM) and the Sufi-inspired Darul Arqam movement taking over the campuses and urban settlements of the country.

The emergence of movements like Darul Arqam and ABIM in Malaysia was symptomatic of the changes taking place in Malay-Muslim society as a whole. Thanks to the Islamisation race between UMNO and PAS which had begun in the 1960s, Islamic influences had penetrated even deeper into the political, economic and cultural environment of the Malays in the country. The inflation of Islamic discourse in Malay-Muslim society meant that Malay politics had begun to shift to a more Islamist discursive register. The 1970s witnessed not only the development of new Islamic movements in the country but also the first signs of popular Islamic resurgence that came in the form of Islamic dress, social norms, modes of communication and Islamic literature. Ironically, it was the contestation between PAS and UMNO that helped to create these new Islamist movements.

While their counterparts in Malaysia were being courted by the various Islamist movements and parties like ABIM, Darul Arqam and PAS, the Malay-Muslim students who were studying abroad in Europe were coming into contact with other Muslim students from the rest of the Muslim world. For the first time in history, large numbers of young Muslims- Arabs, Africans, Central Asians, South Asians, Southeast Asians and Europeans - were meeting together in an alien (i.e. nonMuslim) setting. The one common factor between them was that they all belonged to the same faith. Though Malcolm X had gone one step further when he said that all human beings- Muslims and non-Muslims alike- were equal before God because they snored in the same language. 
The universities and polytechnics of London, Manchester, Liverpool, Bradford, Edinburg and Brighton were the places where Malay-Muslim students were learning not only about economics and engineering- they were also discussing the ideas of prominent Muslim thinkers and Islamist activists like Maulana Ab'ul Al'a Maudoodi of Pakistan, Hassan al-Banna of Egypt, Malek Ben Nabi of Algeria and the Islamist intellectual Ismail Raj Faruqi of the United States. (Ismail Raj Faruqi was destined to play a crucial role in this meeting of minds, for he would later help to direct the political career of Anwar Ibrahim. It was Faruqi who prompted Anwar to join the UMNO party in 1982.) They also came to learn more about the experiences of Muslims from other countries by talking with the students who came from there. It was hardly a coincidence, then, that the Malaysian students in Britain (and other Western countries) were more clued up about the latest developments in Iran, Turkey, Pakistan, Algeria and Egypt. And while the governments, media and NGOs of the West were bemoaning the fate of Muslim women and demanding Muslim governments to live up to the standards of the Universal Declaration of Human Rights (which was drafted, we must remember, at a time when most Muslim countries were still the colonies of the Western imperial powers), the younger generation of Muslim students in the West were more concerned about the fate of persecuted Muslim minorities in places like Palestine, Russia, India, Kashmir and the Philippines.

While abroad, the Malay-Muslims students in Britain and the rest of Europe also gained a first-hand impression of what life in the West was really like. Britain in the 1970s was another country altogether compared to what it was in the 1950s. The rise of xenophobia and racism, the climate of prejudice towards foreigners (even if they happened to be foreign students who were paying full fees at their colleges), the deteriorating economy (made worse by the oil crisis of 1973), growing homelessness and unemployment, the evident breakdown of law and order in the inner cities, the growing problem of domestic violence, rape, single-parent families (still a taboo subject for most Asian and Muslim societies), the fear of an impending nuclear holocaust and a total breakdown of the eco-system in the most developed parts of North-western Europe- all contributed to the 
growing feeling that Europe was the 'sick man of the world' and that the European model of development was leading nowhere fast. As Chandra sums it up:

It is because of all this that the West was no longer seen as a civilisation worthy of emulation. It appears to be aimless and uncertain at this juncture in history. Malay-Muslim students in universities in the United States, Britain and Australia (were) among those who were totally convinced that the West had reached its twilight. ...Confronted by a new reality, the later generation of Malaysian students abroad had no doubt at all that Islam was about to herald the new dawn of a new civilisation. ${ }^{30}$

The sense of Islam's manifest destiny was made all the more strong by the contact with other Islamist leaders and movements that were based in Europe at the time. For Britain was also a good place to make contact with a variety of Islamist opposition parties, clandestine networks and underground movements. It was here that the MalaysianMuslim students first encountered the representatives of groups like the Jama'at-i Islami, Ikhwan'ul Muslimin, the Palestinian Liberation Organisation (PLO), Hizbullah, Hamas, Muhamadiyyah and others. Ironically, it was the experience of being in Britain that brought MalayMuslim students closer to each other and their Muslim brothers and sisters from the rest of the Muslim world-a stark reminder of how drastically the political geography of the Muslim world has changed since the $19^{\text {th }}$ century.

In time these Malaysian students began to form a number of organisations and networks of their own. The Malaysian Muslim student organisations that were based in Britain began to learn from other Islamist student organisations and networks, and they adapted the methods and tactics employed by these organisations to suit their own needs.

One of the results of this networking process was the formation of the Islamic Representative Council (IRC) which began to show itself on the (British and Malaysian) campus scene by the 1970s. During the early stages of Islamist student activism between 1969 to 1976 the

${ }^{30}$ Ibid., pp. 34-35. 
Muslim student movements in the local campuses were dominated by Malay-Muslim students from the arts faculties. This situation only began to change in by the mid-1970s when the leadership of the local and international university student movements fell into the hands of Malay-Muslim scholars from the science stream, who were more rigid and militant in their approach. These students eventually formed the IRC which adopted a more covert approach to their activities. The IRC organised itself in the form of cells which then penetrated into the local campuses and other existing organisations in order to spread their Islamic message from within. Shamsul Baharuddin notes that:

Because this organisation was born outside the Malaysian socio-political milieu and was informed mainly by sectarian Islamist groups based in the Middle East and South Asia, its focus was more on religion for religion's sake than religion for society's sake. The IRC saw ABIM's brand of Islam as too 'spicy' and impure (re. tolerant of heterogeneity), unlike theirs which was more true to the original and pure (re. demanding total response)....The IRC group adopted the educational approach or tarbiyyah, through the formation and spread of small cells among the students. The denounced the Malaysian government as un-Islamic and accused it of upholding a secular and infidel system of rule. Recruiting from among the science students, the IRC adopted what could be seen as a black-and-white approach to Islam. In their view one either practiced Islam in a complete way or was an infidel; one either fought for Islam or was irreligious, if a member of an Islamic group one had to be a full-time dakwah activist, and not merely a sympathiser. ${ }^{31}$

The appearance of Islamist youth movements and organisations like ABIM, the IRC and Darul Arqam were among the first signs that the UMNO-led government's developmentalist paradigm was losing its appeal to the Malay-Muslims of the country.

In an ironic twist of fate, the UMNO-led government had managed to sow the seeds of its own downfall by creating these educational institutions that it could not control effectively. While UMNO could prove its worth by building such institutions of higher

${ }^{31}$ Shamsul A. Baharuddin, Identity Construction, p. 215. 
education for the benefit of the Malays, it could not control what was happening in them. Likewise, the UMNO-led government had tried to demonstrate its concern for the plight of the Malays by sending thousands of poor Malay students to study abroad- but it was unable to monitor and control the activities that took place in those centres of learning so far away. The universities and colleges (both local and foreign) were meant to reproduce the Malay-Muslim middle-classes who would later go on to work within the economic and political institutions founded by UMNO and the government, but they had instead been turned into breeding grounds for Islamist radicals and activists who were openly challenging the ideology of UMNO. In the minds of the technocrats and nation-builders of Malaysia, something had clearly gone wrong.

In a sense, 'Europe' had let the Malaysian government down, in more ways that one. It was hoped that the Malay-Muslim students who were sent to the West would come back bringing with them valuable knowledge and technical know-how that was meant to help Malaysia catch up in the development race. They were meant to be the future technocrats, academics, economists and corporate elite who would uplift the economic and political lot of the country, thereby helping to create the economic 'miracle' that everyone had longed for. But the mistake of the Malaysian technocrats and politicians lay in their assumption that there was still one, singular, unified Europe that they were sending their students to. In reality Europe had already become a contested concept and a contested space. In the end the Malaysian students came back with their beards, skull caps, tasbibs and bijab, homesick and dreaming of returning to the Golden Age of Islam.

\section{E. Come Home, Young Islamist: the Return of the Second Generation of Malay-Muslim Students from Europe and Their Impact on the Malaysian Political Scene}

'They (the UMNO-led government) thought that by sending our students to the West they could secularise them and make them less Muslim. But Alhamdulillah, thanks to Allah all our students have grown even more Islamic and have joined us (the Pan-Malaysian Islamic Party, PAS).' 
Speech by Ustaz Hadi Awang, Vice-President of PAS (The PanMalaysian Islamic Party) during the election campaign of 1999.

The Malaysia that the students were returning to was also a radically different one. As pointed out earlier, Malaysia was not immune to the changes that were taking place in the rest of the Muslim world and these changes were bound to have an effect on how Muslims the world over viewed themselves and their relationship with the Other. The rise of political Islam or Islamism from the mid-20 ${ }^{\text {th }}$ century onwards furnished the discourse of Muslim political elites, scholars, intellectuals, artists and Islamist activists with a new and radically different image of Europe that would remain for a long time to come.

By the 1980s, these changes had led to the rise of a new generation of politicians and Islamists in Malaysia as well. In 1981 Malaysia witnessed the coming to power of Dr. Mahathir Mohamad the staunchly pro-Southern, anti-Western Malay nationalist leader who was one of the few UMNO politicians who had dared to defy the will of the anglophile Tunku Abdul Rahman in the 1960s. (For his sins, Dr. Mahathir was temporarily kicked out of the party in 1969). One year later the UMNO party welcomed the young and charismatic ABIM leader Anwar Ibrahim who had abandoned the Islamist movement he had formed and led- much to the shock and dismay of the Islamists who wanted to see him take over the leadership of the Islamist party PAS.

In the same year (1982) the Islamist party also experienced an internal coup of sorts when the conservative 'ulama' faction took over the leadership of PAS. This led to the rise of a new generation of ulama-activists, many of whom were educated both in the Arab world and the West. They included men like Ustaz Yusuf Rawa, Abdul Hadi Awang and Fadzil Mohamad Noor (Many of these leaders were themselves ex-student activists who had studied at the local and foreign universities and were linked to ABIM or the IRC).

The 1980s and 1990s witnessed a radical reversal in the way in which the 'West' was viewed by the new political elite and middleclasses in Malaysia. Dr. Mahathir made his own views abundantly clear when he announced that henceforth Malaysia would be 'looking East' instead of to the West for inspiration and assistance in its development. 
In 1981 he also launched the 'Buy British Last' policy- which was warmly received by many sections of Malaysia's new society.

Apart from his diatribes against the West with its 'conspiracies' against the Muslim world, Dr. Mahathir also became known as one of the major proponents of the so-called 'Asian values' school. (The other advocate of the same school being Lee Kuan Yew, Premier of Singapore). Mahathir argued that the Western understanding of human rights and entitlements was a culturally specific concept that had no relevance for Asians or non-Europeans in general. Along with Lee Kuan Yew and a handful of other Asian leaders, he began to call for an 'Asian' interpretation of human rights that linked fundamental freedoms to basic obligations to society and the State as well. I have argued elsewhere, that this reactive approach to Human Rights was based on two fundamental premises- the rejection of all things Western; and a call for a return to a politics of authenticity predicated on essentialist notions of what an Asian identity was. ${ }^{32}$ Surfing on the crest of the latest postmodern anti-universalist wave, leaders like Mahathir were actively engaged in an attempt to create a new counter-hegemonic discourse that was rooted in a localised idiom. Not surprisingly, in the case of Malaysia this idiom was both Asian and Islamic at the same time.

But the image of Europe was something that neither the leaders of UMNO nor the leaders of PAS could do away with. As Dr. Mahathir launched his own state Islamisation programme in 1982 (which led to the opening of the International Islamic University, the Malaysian Islamic Bank, the Pilgrimage Fund and a network of Islamic thinktanks, research centres and institutes), he and the other leaders of UMNO were scathing in their attacks on the West which was labelled as morally degenerate, corrupt and intellectually bankrupt in toto. The leaders of PAS were careful not to be left behind. In their continued assaults against the government of Dr. Mahathir, they made every effort to establish yet another chain of equivalences between the government

${ }^{32}$ See: Farish A. Noor, "Values in the Dynamics of Malaysia's Internal and External Political Relations", in Han Sung-Joo (ed.), Changing Values in Asia: Their Impact on Governance and Development, (Tokyo: Japan Centre for International Exchange (JCIE), 1999). 
and the evil, secular culture of the West.

Damned by both conservative and Islamist alike, Europe and the 'West' in general became the depository of all that was corrupt, base, evil and degraded in the world. But the most bitter and devastating attacks on the European idea came from a Malaysian Islamist intellectual and scholar who was himself the product of Western education and upbringing: Syed Naquib al-Attas.

\section{All that Europe Ain't: Muslim Malaysia vs the Secular West in the Reversed Orientalism of Syed Naquib al-Attas}

'Islam totally rejects any application to itself of the concepts of secular, secularisation or secularism as they do not belong and are alien to it in every respect'.

Syed Naquib al-Attas, Islam and Secularism

It could be argued that no Malaysian intellectual or scholar has been able to demonise the West as effectively as the prominent Islamist thinker Professor Syed Naquib al-Attas. ${ }^{33}$ Al-Attas, who was himself the product of Eton, Sandhurst and the School of Oriental and African Studies (SOAS) in London, became a source of inspiration for an entire

${ }^{33}$ Syed Naquib al-Attas is perhaps one of the most well-known if not controversial Islamist thinkers in Malaysia today. His influence extends well beyond the confines of academia and he has played an important role in the cultivation of the Islamic elite in the country. He comes from one of the most famous aristocratic families in the south and is of mixed Malay-Arabic stock. In his youth he studied in England, first at Eton and then at Sandhurst Military Academy and later at the School of Oriental and African Studies (SOAS), University of London. His early academic researches were into the fields of Malay Sufism and literature. His fame was assured when he published his two-volume dissertation The Mysticism of Hamzah Fansuri (1965, published 1970). He later developed much of his educational philosophy with this Sufi influence clearly apparent in his work. He also prides himself as a designer, calligrapher and artist. He was given the opportunity to create The International Institute for Islamic Thought and Civilisation (ISTAC) in 1991 and in 1993 he was awarded the Al-Ghazali Chair of Islamic Philosophy by the Malaysian government (The award was presented by none other than his own student-turned-politician Anwar Ibrahim, who was then a Minister in the Cabinet). He was awarded the membership of the Royal Jordanian Academy in 1994 and honoured with an honorary doctorate from the University of Khartoum in 1995. 
generation of Malay-Muslim university students. He later came to head the International Institute of Islamic Thought and Civilisation (ISTAC) that is based in Kuala Lumpur. ${ }^{34}$ But al-Attas's most popular and influential book has always been 'Islam and Secularism', which was first published by ABIM in 1978 (the same year that Edward Said's Orientalism was published in the West) and which became the standard reference for an entire generation of middle-class professionals, politicians, students and teachers in the country.

Al-Attas's impact on the student body was considerable. He was the intellectual figurehead behind the Malaysian Islamic Youth Movement (ABIM) as well as the personal guide of the young ex-ABIM leader-turned UMNO politician, Anwar Ibrahim. ${ }^{35}$ In Malaysian academic circles, Naquib al-Attas is known as the Malaysian proponent of the project of 'Islamisation of knowledge'. In high-level social and

${ }^{34}$ The International Institute for Islamic Thought and Civilisation (ISTAC) was formed in 1991. It was, from the very beginning, the brainchild of its founderdirector, Syed Naquib al-Attas. Anwar Ibrahim, the ex-president of ABIM, was the first Chairman of ISTAC. In its early years, ISTAC received much support and patronage from the Malaysian government, both in terms of financial assistance as well as publicity and the endorsement of its activities by the government. In the preface of the second edition (1993) of his book 'Islam and Secularism', al-Attas outlines the mandate and agenda of his institute: 'Among its most important aims and objectives are to conceptualise, clarify, elaborate scientific and epistemological problems encountered by Muslims in this modern age; to provide an Islamic response to the intellectual and cultural challenges of the modern world and various schools of thought, religion and ideology; to formulate an Islamic philosophy of education; including the definitions, aims and objectives of Islamic education, to formulate an Islamic philosophy of science'. (p. xiii). In short, the aim of ISTAC was to spearhead al-Attas's own project of the Islamisation of knowledge which in turn is intimately linked to his political project of the revival of the spirit of Islam through the creation of a new class of intellectually competent and knowledgeable Islamic leaders who conform to the rules of adab and the social and political hierarchies al-Attas regards as essentially Islamic. Al-Attas was given a lot of freedom in designing ISTAC, down to its architectural details. The main building which houses the library, conference hall and research units was designed by him and reflect strong Hispano-Moorish styles and features.

${ }^{35}$ Chandra Muzaffar has noted that 'within the country the person who had the greatest influence on Anwar Ibrahim in his ABIM years was Syed Naquib al-Attas, then professor of Malay Studies at the National University of Malaysia;' Chandra Muzaffar, Islamic Resurgence in Malaysia, p. 54, n. 23. 
political circles he is well received thanks to his mixed Malay-Arabic ancestry, his aristocratic background and his intimate links to the early founders of the dominant Malay conservative UMNO party. He was, in other words, clearly an establishment figure and his institute (ISTAC) was firmly located at the centre of the government's network of Islamic research and academic institutes. From his interest in Sufism al-Attas developed a complex philosophy of Islamic education which laid great emphasis on the role of order and scriptural authority. Critical observers have suggested that this may explain both the appeal of al-Attas to the Malaysian political establishment as well as his following among a legion of enamoured Malay-Muslim scholars and student-activists, all of which contributes further to the cult of personality surrounding the man. ${ }^{36}$

The philosophy of al-Attas can be summarised as follows: Like Khomeini, al-Attas regards Islam as a complete, totalised, exclusive and unique system of belief and thought. It is, for him, the sole religion which possesses a 'salvatic mission' and the only one with truly universalistic claims. ${ }^{37}$ Islam has therefore nothing to learn from other belief and value systems, and Muslims must reject the relativisation of values and beliefs which has become en vogue of late thanks to the scourge of Western secularism. Secularism, on al-Attas's terms, is fundamentally a product of the Western historical experience. ${ }^{38}$ Thus from the outset it is presented as something alien to the Muslim world

${ }^{36}$ See: Mona Abaza, Retbinking the Social Knowledge of Islam: Critical Explorations in the Islamisation of Knowledge Debate between Malaysia and Egypt, unpublished Doctoral thesis for the Wissenschaftskolleg zu Berlin, Berlin, 1998, esp. Chapter 6, pp. 85-107.

${ }^{37} \mathrm{Al}$-Attas argues that of the three main Semitic religions Judaism, Christianity and Islam), it is Islam that possesses a 'salvatic impulse' to save the rest of humanity. Judaism, and to a lesser extent, Christianity, are fundamentally tribal religions limited to a select people while the message of Islam is open to all. (Ironically, al-Attas later goes on to attack what he calls the de-Arabisation of Islam by secular Muslims, p. 127). Likewise, Buddhism, Hinduism, Confucianism and other Chinese beliefs are not guided by salvatic missionary impulses. These are also nation-based collective belief systems for him (pp. 98-99). 
and the Muslim mind.

For al-Attas Secularism is a Western and eurocentric belief and value system which confines human existence to the level of the profane, material and physical world. It has been one of the tools used by the West in its war against Islam and its effort to 'de-Islamize' Muslim intellectuals. ${ }^{39}$ Western secularism leads in turn to the promotion of secular (Western) sciences and knowledge such as biology, physics, anthropology and the humanist sciences. ${ }^{40}$ It promotes humanism and positivism as the benchmarks of epistemological certainty and Truth. These 'lesser' or 'lower' knowledges then contribute to what al-Attas calls the 'levelling' of the (Muslim) mind, which creates the impression

${ }^{38} \mathrm{Al}$-Attas insists that 'the major problems that beset Muslim society today must be understood against the background of historical confrontation which Western culture and civilisation had perpetuated against Islam' (p. 87). He argues that secularism, as developed within the West, has become one of the major intellectual and cultural tools used by the West to undermine the integrity of the Muslim mind and the faith of the Muslims: 'the problems (of Muslims) are caused through the introduction of Western ways of thinking and judging and believing emulated by some Muslim scholars and intellectuals who have been unduly influenced by the West and overawed by its scientific and technological achievements' (p. 15).

${ }^{39}$ Syed Naguib al-Attas, Islam and Secularism, (Kuala Lumpur: Angkatan Belia Islam Malaysia (ABIM), 1978), p. 16 and also: pp. 124-126.

${ }^{40} \mathrm{Al}$-Attas condemns the pervasive spread of secularism among Muslim intellectuals via the humanist sciences that they have learnt from their western teachers thus: 'The secular scholars and intellectuals among the Muslims derive their aspirations mainly from the West. Ideologically the belong to the same line of modernist 'reformers'... The secular scholars and intellectuals among us refuse to listen and pay attention (to Islamic teachers) but hang instead upon every word taught by their western masters in the various branches of the knowledge of the sciences, particularly in that branch known as the human sciences.' (pp. 124-125). Elsewhere he attacks these various schools of humanist knowledge as being fundamentally limited, inferior and antithetical to the spirit and philosophy of Islam: 'In de-Islamizing the Muslims, the Western administrators and colonial theorists have first severed the pedagogical link between the Holy Qur'an and the local language by establishing a system of secular education. At the higher levels linguistics and anthropology are introduced as the methodological tools for the study of language and culture, and Western values, models and Orientalist scholarship and philology for the study of literature and history.' (p. 126). These humanistic sciences, for al-Attas, are all mainly directed towards humanising the outlook of Muslims and to de-sacralise their religion and worldview so that they in turn adopt a secular outlook on life as well. 
that all knowledge and truth is relative, contingent, historically and culturally specific and arbitrary. ${ }^{41}$

The effect of Western-inspired and Western-directed secularisation is that it has brought about a state of total moral and epistemological confusion in the Muslim world. Muslims no longer lived in a God-centred universe as soon as they receive their knowledge (and doctorates) from the West. They have become confused about their true purpose in life, their obligations and priorities as well as the social and cultural hierarchies that once governed the universe of Muslims the world over. ${ }^{42}$ While great men of learning once governed Muslim society, Muslims are now being ruled by technocrats and politicians instead. While Muslims once lived in an artistic and cultural milieu of their own, the Muslim world of belle-lettres is now taken over by hacks from the world of common journalism of the awamm (masses) instead. And worse of all, while at one time savants of scholarly vision and purpose (like Naquib al-Attas himself, presumably) once enjoyed the status of illuminati and guides to rulers and peasants alike, this coveted role has now been handed over to lesser academics schooled in Western political science, economics and other such vulgar disciplines of the bazaar. It is hardly a surprise that the homesick Malaysian Muslim students who were longing for a return to the prestine golden age of Islam found a welcoming port in the Utopian writings of al-Attas.

Al-Attas's attack on 'secular' and 'Europeanised' (re: Western trained or educated) intellectuals and political leaders in the Muslim world falls back on his own (Western) military training ${ }^{43}$ and employs the metaphors of battlefields and troop movements. In his polemic against these insidious 'agents of Western secularism', al-Attas only

${ }^{41}$ Syed Naguib al-Attas, Islam and Secularism, p. 129.

${ }^{42} \mathrm{Al}$-Attas contends that 'In respect of the individual, the confusion in knowledge (caused by secularism) creates in him an overweening sort of individualism: he thinks himself the equal of others who are in reality superior to him, and cultivates the immanent arrogance and obstinacy and tends to reject authority', (p. 108).

${ }^{43}$ It must be remembered that Syed Naquib al-Attas was actually trained at the Sandhurst Military Academy in Britain. He later received the King's commission and served in the Royal Malay Regiment of the Malayan armed forces and took part in the military campaign against the communists during the Emergency of 1948-1960. 
stops short of calling them heretics in the eyes of Islam:

(They) have, because of their influential positions in Muslim society, become conscious or unconscious disseminators of unnecessary confusion and ignorance ${ }^{34}$

...They have all become conscious or unconscious agents of Western culture and civilisation, and in this capacity they represent what we have identified as the external sources of our Muslim dilemma. But their existence among us as part of the community creates for us the situation where what was once regarded as the external has now moved in methodically and systematically to become internal. In their present condition they pose as the external menace which has become a grave internal problem, for intellectually, dar al-harb has advanced within daral-Islam; they have become the enemy within' 45

Like all the Islamist thinkers and activists before him, al-Attas longs for the restoration of his vision of pure and original Islam, shorn of all contaminating traces of Europe and the West. Echoing the ideas of Hassan al-Banna (the founder of the Ikhwan'ul Muslimin of Egypt), al-Attas believes in the creation of an intellectual and political leadership made up of spiritually inclined rulers. "The men of intellectual and spiritual discernment and virtue, the savants, saints and sages." ${ }^{46}$ After unleashing his polemics against all and sundry, alAttas prescribes his own unique solution to what he regards as the malaise of the modern Malays. His call for a return to the fundamentals of adab (social customs) invariably betrays the scriptural authoritarianism and intellectual elitism that lies at the heart of his entire educational and political philosophy. Having attacked the institution of modern (re. Western) politics and Liberal Democracy, al-Attas proposes that the leadership of Muslim society should go to those who 'possess the intellectual, spiritual and linguistic prerequisites of Islamic knowledge and epistemology ${ }^{\text {'7 }}$ and who should not 'be denied their rightful place to lead' ${ }^{48}$. The socio-political order that alAttas envisages is certainly not a democratic or egalitarian one, but

\footnotetext{
${ }^{44}$ Syed Naguib al-Attas, Islam and Secularism, p. 16.

${ }^{45}$ Ibid., p. 128; italics ours.

${ }^{46}$ Ibid., p. 124.

${ }^{47}$ Ibid., p. 124.
} 
one founded instead on his notion of an ideal Islamic society founded and shaped by a conservative reading of adab, where "knowledge and being are ordered hierarchically. ${ }^{49}$

Bearing in mind the conservatism and elitism that is clearly evident in the writings and ideas of Syed Naquib al-Attas, one can see precisely how and why such a thinker would be useful and appealing to the conservative leadership of a party like UMNO and the technocrats of a modern state like Malaysia.

But the ideas of al-Attas also had an enormous appeal for a whole generation of Malaysian Muslim youth who were returning from their studies abroad, disillusioned with the broken promises of the West. He had overturned the violent hierarchies of classical Orientalist discourse (something he learnt while at SOAS, presumably) against the very same people who produced it. While Western Orientalists had configured non-Europeans in terms of what they lacked (rationality, modernity, progress), al-Attas had done the reverse by characterising Europe in terms of what it lacked (and what Islam possessed in abundance), namely order, discipline, morality, tradition, honoured customs, purity and spirituality. By repositioning Islam at the centre of an Islamocentric worldview the way he did, al-Attas had placed London, Paris and New York at the margins of a new world order whose star was on the rise. For thousands of young Malaysian and non-Malaysian students, al-Attas's grand project of reconstructing Islamic knowledge anew (complete with an epistemology and genealogy it could call its own) seemed to be the antidote to the social ills of the West (and the 'Westernised' East).

Yet ironically, the rise of Syed Naquib al-Attas, Dr. Mahathir Mohamad and the Islamists of PAS, ABIM and the other Islamist movements in the country would not have been possible without the experience of migration and encounter with the West. For it was the experience of going to Europe that provided the conservative nationalists and Islamists of Malaysia with the discursive raw material for the anti-Western polemics that they later produced.

\footnotetext{
${ }^{48}$ Ibid., p. 129.

${ }^{49}$ Ibid., p. 105.
} 
The Malaysian Muslim students who returned from Europe (and the United States) from the 1970s onwards were a different breed altogether. They were convinced that the European system was no longer a model worthy of emulation and that the future no longer belonged to the West. It was their experience of living, studying and meeting other Muslim students in the West that convinced them that there was another world- the Muslim world- that was presently in a state of flux and crisis, but which could nonetheless be redeemed and reconstructed. The political upheavals that took place in North Africa, Palestine, the Arab world, South and Southeast Asia then also contributed to the feeling of frustration, anger and disillusionment that was soon directed towards the West and their own Westernised elites back home. By the 1970s and 1980s, these students had themselves become part of the political, bureaucratic and economic elite back in their home countries. Their Islamist outlook and openness to Islamist ideas created the conditions that were ripe for a second revival of Islamism on their own shores- and the developments in Malaysia from 1981 onwards serves as a classic case study of this at work.

\section{E. Conclusion: The Ambivalent 'West' in the Psycho-Social Drama of Homesickness and Homecoming}

The first part of this paper was meant to challenge and debunk the notion that travel and communication were and are somehow 'novel' to the Muslim world. There is absolutely nothing that would back up such a claim, though there are still many scholars who sadly continue to evoke the trope of the static Muslim community for the sake of the dramas that they wish to have played out in their own analyses of Muslim society, culture, history and politics. I have argued that travel to the rest of the Muslim world has always been part of ordinary Muslim life for the Malays of the archipelago, and that this process was only brought to a halt due to political circumstances and developments that were beyond their control.

Travel to the West however (and to Western Europe in particular) was of special importance for successive generations of Malay-Muslim political elites and scholars, for whom the idea of European civilisation 
was equated with all that was progressive, advanced, civilised, rational and universal. Up to the mid-20 $0^{\text {th }}$ century, many Malay-Muslim political leaders, scholars and intellectuals still believed that the West stood for a host of positive values and ideals.

This idealised image of the West was effectively shattered by the 1960s and 1970s, and its fall from grace was occasioned by the emergence of new schools of critical thought both within and without Europe itself. Even more ironic was the fact that it was the internal critique within Europe (which began in the 1960s) that helped to open the way for the emergence and entry of Islamism on the political scene both in the local and international context. As the limits to Europe's own claims to universality were challenged and contested from within and without, the possibility of precluding any other alternative claims to universal knowledge and truth was lost.

However, it is important to note that with the decentring of Europe, the non-European world has itself been grappling with the challenge of inventing its own discourse of identity which has often taken a turn towards essentialism and the politics of authenticity. This holds true for the emergence of Islamism as an alternative anti-European discourse as well. And it is important to note, as Sayyid (1997) does, that 'while Islamism is based on the possibility of decentring the West' and that it is 'suspicious of meta-narratives that it considers to be Western', the discourse of Islamism itself has "been presented with all the certainly of yet another meta-narrative. The content of Islamist discourses is replete with grand claims and essentialist categories marshalled in an uncompromising absolutist language." ${ }^{50}$ This as we have seen was clearly the case in the writings of Malaysia's own archIslamist ideologue, Syed Naquib al-Attas.

Thus while Islamism may seem to share some family resemblances (to borrow Wittgenstein's phrase) with the discourses of post-modernity and deconstruction, we cannot forget the fact that it attempts to speak from a fixed position outside the orbit of the West which is nonetheless a privileged (and central) position of its own. Islamist students, activists and intellectuals may have been happy to

${ }^{50}$ Bobby Sayyid, A Fundamental Fear, pp. 117-118. 
rely upon the tools of deconstruction and critical theory as a means to undermine the universalism and centrality of the West, but they were certainly not prepared to use the same tools to radically interrogate their own beliefs and worldview.

Throughout this long and epic story between East and West, Islam and Secularism, the idea of 'The West' has played a pivotal role in the drama of homesickness and homecoming. It has, as I have tried to show, been a major idea that helped to shape the discourse of nationalism and Islamism in Malaysia. The fact that it was Western Europe (and not East Asia, Africa, Latin America or Australasia) that figured so prominently in this discourse of desire and repulsion is hardly an accident or coincidence either. Malaysia's complex and problematic relationship with Europe (and Britain in particular) was rooted in very real (and unequal) relations of power, dominance and dependency which the former initially accepted but came to reject soon after. The circumstances that led to this about-turn were, as I have shown, beyond the control of both sides. Malaysia and Europe were swept along with the rest of the world by the stronger currents of anti-colonialism, antiimperialism and Islamic resurgence during the 1960s and 1970s.

Despite the vehemently anti-Western outlook that many of the 1970s and 1980s generation harbour till today, the 'West' was, and remains, the vital constitutive ingredient that gives this form of radical Islamism its unity of purpose. Europe today still figures prominently in the popular political discourse of Malaysians and the Malay-Muslims in particular. The rise of political Islam in Malaysia (evident in the growing popularity and electoral appeal of the Islamist opposition party PAS and the state's own move towards the Islamist register) betrays the constant need for a constitutive Other that serves as the instrumental fiction which lends coherence to the Islamist project. The 'West', which prided itself for the 'gifts' that it once bestowed on the 'less civilised' nations and peoples who came under its dominance, now finds itself playing the role of the reluctant benefactor once again. For the apparent (and over-stated) 'failure' of the 'West' has been taken as a gift by those who once stood at the margins of its order of knowledge and power. And the bearers of these 'gifts' are none other than the successive generations of Malay-Muslim students who have travelled all the way 
Farish A. Noor

to the 'West', only to reaffirm their own beliefs in themselves, what they have lost and what they seek to regain. 


\section{BIBLIOGRAPHY}

Abaza, Mona, Rethinking the Social Knowledge of Islam: Critical Explorations in the Islamisation of Knowledge Debate between Malaysia and Egypt, unpublished Doctoral Thesis for the Wissenschaftskolleg zu Berlin, Berlin, 1998.

Ahmed, Akbar S., "Islam in the Age of Postmodernity", in Akbar S. Ahmed and Hastings Donnan (eds.), Islam, Globalisation and Postmodernity, London: Routledge Press, 1994.

Alatas, S. Hussein, "On the Need for a Historical Study of Malaysian Islamisation", Journal of Southeast Asian Studies, vol. 4 No. 3, Singapore, March 1963.

Antoun, Richard T., "Sojourners Abroad. Migration for Higher Education in a Post Peasant Muslim Society", in Akbar S. Ahmed and Hastings Donnan (eds.), Islam, Globalisation and Postmodernity, London: Routledge Press, 1994.

Appadurai, A., "Disjuncture and Difference in the Global Cultural Economy", in Public Culture, 2 (2), 1990.

Attas, Syed Naguib al-, Islam and Secularism, Kuala Lumpur: Angkatan Belia Islam Malaysia (ABIM), 1978.

Attas, Syed Naguib Al-, Preliminary Statement on a General Theory of the Islamization of the Malay-Indonesian Archipelago, Kuala Lumpur: Dewan Bahasa dan Pustaka, 1963.

C.C. Brown, The Malay Annals, Oxford in Asia, reprints, Oxford, 1952.

Chaudhuri, K. N., Asia Before Europe: Economy and Civilisation of the Indian Ocean from the Rise of Islam to 1750, Cambridge: University Press, 1990.

Eickelman, Dale F., and Jon W. Anderson, "Redefining Muslim Publics", in Dale F. Eickelman and Jon W. Anderson (eds.), New Media in the Muslim World: The Emerging Public Sphere, Bloomington and Indianapolis: Indiana University Press, 1999.

Fatimi, S. Q., Islam Comes to Malaysia, Singapore: Malaysian Sociological Research Institute (MSRI), 1963. 
Gellner, Ernest, Muslim Society, Cambridge: Cambridge University Press, 1981.

Gordon, Alijah (ed.), The Real Cry of Syed Sheikh al-Hady, Kuala Lumpur: Malaysian Sociological Research Institute (MSRI), 1999.

Gullick, J. M, Rulers and Residents: Influence and Power in the Malay States 1870-1920, Singapore: Oxford Univ. Press, 1992.

Hall, Stuart and Bram Gieben, "The West and the Rest: Discourse and Power", in Stuart Hall and Bram Gieben (eds.), The Formation of Modernity, Cambridge: Polity Press, 1992.

Hamid, Ismail, The Malay Islamic Hikayat, Monograph 1, Kuala Lumpur: National University of Malaysia (UKM), 1983.

Kadir, Munshi Abdullah Abdul, Sejarah Melayu or Salalatul Salatin (The Malay Annals), Djakarta and Amsterdam: Djambatan Press, 1952.

Kramer, Martin, Islam Assembled: The Advent of the Muslim Congresses, Cambridge: Columbia University Press, 1986.

Laclau, Ernesto and Chantal Mouffe, Hegemony and Socialist Strategy: Towards a Radical Democratic Politics, London: Verso Press, 1985.

Miller, Harry, Prince and Premier: A Biography of Tunku Abdul Rahman Putra Al-Haj, London: Harrap, 1959.

Milner, A. C., Islam and the Muslim State in Islam in Southeast Asia, M.B Hooker (ed.), New York: EJ Brill, 1988.

Muzaffar, Chandra, "Islamic Resurgence: A Global View", in Taufik Abdullah and Sharon Siddique (eds.), Islam and Society in Southeast Asia, Singapore: Institute for Southeast Asian Studies (ISEAS), 1986.

Muzaffar, Chandra, Islamic Resurgence in Malaysia, Petaling Jaya: Fajar Bakti Press, 1987.

Muzaffar, Chandra, Power and Dialogue-Asymmetries in the Global Intercultural Dialogue, paper presented at the conference "Visions 2000”, House of World Cultures, Berlin, 2000.

Muzaffar, Chandra, Protector? An Analysis of Leader-Led Political Relationships in Malay Society, Penang: Aliran Kesedaran Press, 1979. 
Nagata, Judith, The Reflowering of Malaysian Islam, Vancouver: University of British Columbia Press, 1984.

Noor, Farish A, "Values in the Dynamics of Malaysia's Internal and External Political Relations", in Han Sung-Joo (ed.), Changing Values in Asia: Their Impact on Governance and Development. Tokyo: Japan Centre for International Exchange (JCIE), 1999.

Rudoplh, Susanne Hoeber, Religion, States and Transnational Civil Society, in Susanne Hoeber Rudolph and James Piscatori (eds.), Transnational Religion and Nation States, Colorado: Westview Press, Boulder, 1997.

Said, Edward, Orientalism, London: Harmondsworth, Penguin Books, 1978.

Sayyid, Bobby, A Fundamental Fear: Eurocentrism and the Emergence of Islamism, London: Zed Books, 1997.

Siddique, Sharon, "Conceptualising Contemporary Islam: Religion of Ideology?", in Ahmad Ibrahim, Yasmin Hussain and Sharon Siddique (eds.), Readings on Islam and Society in Southeast Asia, Singapore: Institute for Southeast Asian Studies (ISEAS), 1985.

Thomas, Nicholas, Colonialism's Culture: Anthropology, Travel and Government, London Verso Press, 1995.

Tibbetts, G. R., Arab Navigation: Being a translation of the Kitab al-Fawa'id fi usal al-Babr wa'-Gawa'id of Ahmad ibn Majid, London: Luzac Press, 1971.

Watson, Barbara and Leonard Andaya, A History of Malaya, London: MacMillan Press, 1982.

Wolpert, Stanley, Zulfi Bhutto of Pakistan: His Life and Times, Karachi: Oxford, 1993. 